\title{
Limited access to land rights for the powerless in Potchefstroom ${ }^{1}$
}

\author{
N.S. Jansen van Rensburg \\ Dept. of Sociology (Social Anthropology) \\ Potchefstroom University for CHE \\ POTCHEFSTROOM
}

The strongest man is never strong enough to be always master unless he transforms his power into right and obedience into duty - Jean-Jacques Rousseau.

\begin{abstract}
Limited access to land rights for the powerless in Potchefstroom

The concept of structural violence is useful in the analysis of the land issue in urban areas in South Africa, more specifically in this case, the town of Potchefstroom from 1.901 to 1952 . By institutionalising racism, a situation of inequality of power and opportunities has been brought about. This can best be understood within the rigidly stratified system of apartheid: it imposed an alternative and restricted structure of land use on the specific subordinate category in the area of study. By creating this alternative system, those in power excluded the powerless from the "central" system. The concept of an alternative system can be understood in terms of the theory of structural violence, to explain the difference between the real and the potential attainment of human somatic and psychical abilities. Thus, structural violence is built into the very structures of a society and is concretized in unequal power and, consequently, unequal opportunities in life. Clearly, group and institutional discrimination in this area can be viewed as a form of structural violence because of
\end{abstract}

1 A draft of this paper was presented at a meeting of the Association for Anthropologists of Southem Africa held during September 1987 at the University of Cape Town. Helpful comments on this draft have been received from the following colleagues; J.H. Booyens, A.S. de Beer, L.M. du Plessis, H. van der Wateren and P.J. van Niekerk. 
Limited access to land rights for the powerless in Potchefstroom

the dire consequences, the indirect methods and the impersonal nature of these actions.

\section{Introduction}

The purpose of this study is to evaluate the development of the right to land of specifically defined, subordinate South African population categories in the residential area of Potchefstroom. I wish to argue that the concept of structural violence is useful in the analysis of the gathered information. By institutionalising racism, a situation of inequality of power and opportunities has been brought about. This can best be understood within the rigidly stratified system of apartheid: it imposed an alternative and restricted structure of land use on the specific subordinate category. By creating this alternative system, those in power excluded the powerless from the "central" system. The concept of an alternative system was based on a differentiated power system, with clear legality but not legitimacy. This is also related to the perception held by whites in South Africa regarding the social worth of people of colour (cf. Van Onselen, 1982b; Hancock, 1962:317).

The study of the colonial situation as specifically related to the competition for and appropriation of land becomes clear when an important concept coined by Galtung is used (as quoted by Roothman, 1983:33, 38, 41; Kotzé, 1984; cf. also Galtung, 1969:168 et seq.). Galtung uses the concept of structural violence to explain the difference between the real and the potential attainment of human somatic and psychical abilities. ${ }^{2}$ Thus, structural violence is built into the very structures of a society and is concretized in unequal power and, consequently, unequal opportunities in life. One attribute of structural violence can be institutional racism, which is based on the total functioning of vested and respected powers in society, and has visible and definite effects (Roothman, 1983:57, 62; Kotzé, 1984:46). Clearly, group and institutional discrimination in South Africa can be viewed as a form of structural violence because of the dire consequences, the indirect methods and the impersonal nature of these actions (Kotzé, 1984:46).

Galtung (1969:175) also stated that the study of social structure and, specifically that of stratification, is essential for an understanding of the phenomenon of structural violence. Especially in relatively closed stratified

2 Galtung also defined it in a different context, as the cause of the difference between the optimal life expectancy and actual life expectancy (Galtung \& Höivik, 1971:74). 
N.S. Jansen van Rensburg

systems, where ascription of power and privilege is rigid, ${ }^{3}$ the occurrence of structural violence is more intense. In such instances, some individuals or groups are deprived, while others are favoured, based on, for instance, race, class, religion or sex (Rhoodie, 1977:12, 15 et seq.). Access to a society's resources can be denied to deprived groups by laws, customs and rules. The practice of discrimination (structural violence) is therefore the cause of the difference between the attainment of potential and real human, social, economical and political abilities (Rhoodie, 1977:40-44).

What has become evident is how, over the centuries, the whole structure of South African society, because of the differential access to power, determined access to opportunities and resources (cf. Galtung, 1969:171) - of which land (specifically municipal land in this article) is without question the most important. ${ }^{4}$ Against the background of local information, the reasoning of those responsible for the creation of an alternative land occupancy system for "blacks" and "coloureds" in South Africa, becomes clearer. Some authors note an important underlying condition that may be regarded as an independent variable, namely: ".. the degree of discrepancy in the rewards offered by political control and economic power. Where the discrepancies are great, the rate of mobility is diminished and the extent of subculture differences increased" (Tuden \& Plotnicov, 1970:7). The possible rewards of the available resources in South Africa created conditions for the differential access to the "central" system with its accompanying privileges. One way in which this was accomplished, was by statutory measures, which often acted as a blueprint, an abstract, used to threaten people into subordination. This differed from personal violence which was visible, whereas, "the object of structural violence may be persuaded not to perceive this at all" (Galtung, 1969:172-3).

It is also common in systems of social stratification that a structure of layers exists and that within each layer (stratum): "... persons are grouped on the

3 In South Africa, the stratified system is so distinct and rigid that it has been described by observers as a caste system (West, 1971) or a colour caste system (Van den Berghe, 1970:354).

4 Several authors have indicated how the manipulation of health planning and other town-planning ideas have been used to marginalise urban Africans and how, where these plans were used, they were never meant to benefit blacks in general (cf. Swanson, 1977, the "sanitation syndrome"; Caldwell, 1991; Parnell, 1993; Christopher, 1987). In fact, later in this century, all these actions regarding sanitation and town-planning were eventually used as a basis for urban segregation and the "eviction of blacks from the sanitised white city" (Pamell, 1993:487). 
Limited access to land rights for the powerless in Potchefstroom

basis of status criteria, and the arrangement of these layers (strata) is of a hierarchical order indicating differences of social worth associated with the strata or with the statuses which the strata respectively incorporate" (Tuden \& Plotnicov, 1970:3). This differential view of social worth taken by whites in South Africa has repeatedly been indicated. This is associated with the (perceived) necessity of having an elaborate and well-defined ideological system. It has also been suggested that "... where there are great discrepancies in the rewards offered by political control and economic power, the ideologies supporting the stratified groups and validating the inequities within the social structures will be strong and clear" (Van den Berghe, 1970:349). Although a distinct and organisationally supported ideological system such as apartheid was only created in the forties and fifties of this century, its roots clearly lie much deeper and its basis is much broader than is sometimes assumed. These are to be found in the extended practice of structural violence over the centuries.

This article regards the very old concept of structural or indirect violence as useful in partially explaining the South African system of land rights, as manifested particularly in the area of Potchefstroom. This concept and its connotations have changed over time, have been criticized for being too broad (Kotzé, 1984:45), and unfortunately have not made a significant impact on South African scholarship. Still, this concept has retained a certain basic constancy in its general development. In the earliest (1775) accounts referring to the phenomenon of structural violence, references were made to the strong oppressing the weak under cover of the law and of the man of property crushing, under the weight of his prerogatives, the man who lives by the work of his hands (Roothman, 1983:1).

A study has been made of municipal documents of Potchefstroom, selecting the period of administration mainly from 1901 to 1952, because of the rich and detailed nature of the documents from this period and because the idea for the creation of Ikageng, a new residential area for "blacks", was already evolving at the end of this period. Some references will also be made to other periods of administration. 5 This study pays particular attention to the experience and

5 The following authorities administered Potchefstroom during different periods: from 1842-1869, the central govermment of the South African Republic (ZAR); from 1869 to 1889, the City Council (Stadsraad) of Potchefstroom; from 1889 to 1900, again the central government of the ZAR; from 1900 to 1902, the British occupation forces; from 1902 to 1903, the Health Committee; and, since 1903, Potchefstroom Municipality (Potchefstroom, 1939:98 et seq.). These authorities functioned in four eras viz. the rule of the South African Republic (ZAR); the time 
N.S. Jansen van Rensburg

reaction of a subordinate category against the background of actions and measures taken by a dominant category mainly regarding the right of access to land in an urban area, namely Potchefstroom. Those referred to as the dominant category were in a powerful position because of their political and official situation or because of their being favoured as "whites". 6

In this article the term subordinate category (sometimes people of colour) will be used as a comprehensive term indicating all individuals classified as "blacks" (those using Bantu languages), and "coloureds" (people of "mixed" origin, and Afrikaans-speaking) by South African law since 1950. This is also practical from a scientific viewpoint, because of the problematic nature of racial classification (SAIRR, 1949-67; Horrell, 1958; Theron-Kommissie, 1976; Van der Vyver, 1985; Boonzaier, 1988) and because, especially in the early years, ${ }^{7}$ these categories were often treated similarly by officials. When relevant, and when a distinction can be made between these categories, the statutory terms "coloured" and "black" (over some years the latter term changed from native to Bantu to black) will sometimes be used. The other coloured category, which officially comprised Indians or Asians, is excluded from this study.

of British military occupation; British colonial rule and the rule of the Union of South Africa.

6 In a review of the urban historiography Maylam (1995) indicates that it is difficult to isolate dominant motives or imperatives of urban racial segregation in South Africa. He discusses motives such as colonialism, racism, class, the "sanitation syndrome" and material interests, but comes to the conclusion that "Segregation was essentially a form of spatial control over residential space". However, even the "... segregated space set aside for the black underclasses also had to be subjected to control" (Maylam, 1995:29) by means of housing policy, "native administration", and access to municipal political space by way of influx control and pass laws. Maylam's views dovetail with the main thrust of this article.

7 Complicated terms existed for more than a century in Potchefstroom. Officials in the years covered in this article, acted in an ambiguous way in the categorization and treatment of so-called coloureds and blacks, and later they manipulated the situation to the benefit and convenience of one section of the population. Broadly speaking the same tendency was also found in the spheres of school and church, where initially the main distinction between "natives" and "coloureds" was based on language difference (cf. Jansen van Rensburg [1985] for a more detailed discussion.) 
Limited access to land rights for the powerless in Potchefstroom

Potchefstroom, probably the first extensive Boer immigrant settlement in the Transvaal, and the first capital of the Zuid-Afrikaanse Republiek, has always had some inhabitants of mixed origin who accompanied the Boer migrants from the Eastern Cape. The indirect rule of Mzilikazi's Ndebele, up to at least 1832, caused extensive disruption for the Sotho-speaking inhabitants well into the Vaal River and Mooi River areas (Rasmussen, 1978:48, 49, 57, 61, 94). The immediate surrounding area was partly depopulated of its Tswana-speaking inhabitants at the time of Boer settlement (1838) as the result of the intrusion of Mzilikazi. After the defeat of Mzilikazi, Tswana-speakers gradually moved back into the area and into the newly-founded town, Potchefstroom (Van Coller, 1983:6, 26).

From early in the history of Potchefstroom, all individuals of colour lived either in town or in a separate area called a "native location". This "location", which was founded as the result of a decision made by the City Council in 1888, was later (1951) called Willem Klopperville. Bantu-speaking and Afrikaansspeaking people of mixed parentage, who were respectively classified by law as "natives" 8 and "coloureds" since 1950, lived together in the "location". In 1959 the Bantu-speaking inhabitants were moved to Ikageng, a newly created township. From 1969, the central government also compelled those individuals classified as "coloureds" to move to the present Promosa, which was proclaimed a "coloured area" under the Group Areas Act (36 of 1966).

\section{Traditions of land ownership of Boers and British}

Knowledge regarding the Western-influenced common principles of land ownership as perceived by the Boers and British will elucidate the decisions of their political leaders, especially regarding the exclusion of subordinates from the system of land ownership, also in the Potchefstroom residential area:

* Early customs of acquiring land by the Boers and the British were sometimes similar to the practices of the Tswana-speakers, i.e. "incomplete" land tenure. A few examples will suffice. The Dutch East India Company (1652-1795) gave leeningsplaatsen (loan farms) on which no rent was payable, only a recognitie (recognition). The authorities could reclaim this land whenever they wished to do so without paying compensation. To this system was added the vryplaasstelsel (free farms system), which could either be used by paying rent or deposit, in which

8 Before 1950 it was not uncommon to use the term "native" to include both Bantu speakers ("blacks") and people of "mixed" origin ("coloureds"), whereas the latter were mostly Afrikaans-speaking. 
N.S. Jansen van Rensburg

case a map and title deed could be acquired by an individual. In 1813 the British Governor, Sir John Cradock, limited the system of land tenure by proclamation. Only two forms of land ownership were then recognized, namely freehold and perpetual quitrent. For these systems a landowner received a proper written title deed and a map indicating the boundaries of the land. Specific proclamations referred to, implied full ownership, the right to free development, testamentary disposition and alienation (Van der Merwe, 1989:585-590). In the time of Andries Stockenström, "request" tenure allowed Boers to request a quantity of unoccupied land by paying for the expense of measurement, and a quitrent (cf. Davenport \& Hunt, 1974:6-7). In the ZAR an informal system of tenure allowed individuals, on the issuing of certificates of burgher (citizen) rights, the right to select a farm on open ground. When title had been issued, quitrent became payable (Davenport \& Hunt, 1974:6-8).

* Apart from individual and private property, commonage (common land) belonged to the state (or local authority) and everyone could claim a right to it; resources such as water was generally also accessible to all. Land grants to the 1820 British Settlers excluded mineral and road-making rights. These rights were reserved to the Crown. If one abandoned land or did not cultivate the land, it became forfeited to the government (Davenport \& Hunt, 1974:7).

* In later years it was common for individuals to obtain land privately and individually as property. Individual land could be alienated for payment and could be inherited.

* Under specific extreme circumstances, the state/government could expropriate an individual's land.

\section{Customs of land ownership of Tswana-speakers and the limited rights of the servant class}

Land ownership in Potchefstroom should also be seen against the background of the most important elements of the Tswana-speaking category's land ownership rules (cf. Vorster, 1981:56-71; Sansom, 1974:145, 252-6; Olivier, 1980:70-79):

* Allotment of land presumed participation in the life of a specific political ("tribal") unit and non-allotment of land excluded participation in community life; land was only allotted to an individual after acceptance of this individual as a member of the political unit, after which he shared in all the rights and privileges relating to the occupation of land. 
* Public law controlled the political unit's land in its entirety and this control by a political head gave members access to extensive rights (cf. Schapera, 1943:41-44).

* Political office-bearers and senior relatives allotted land to families for occupation and cultivation.

* Suspension of rights regarding land could only take place in the public interest; here, a "tribal" member would be compensated by allotment of other land; a member of the unit, who rebelled against authority or who committed another serious offense, could be banished from the territory by the political head (Schapera, 1943:40, 107-108, 150-152). If a "tribal" member moved away permanently, as happens in emigration, he forfeited his right to the land (Schapera, 1962:21).

* Commonage (non-allotted land) belonged to all and natural resources such as wood and water were accessible to all members of the political unit.

* A household was in lawful control of allotted land and land could be transferred by the lawful occupants or the ward-head or Chief, but without remuneration for the land itself.

* Because the right to land encompassed the privilege of use, enjoyment and disposal, this right can be typified as a protected right of use; also, this right was not private ownership, but vested in the agnate group who had the right to use of the land and the right of allotment to constitutive households.

* "Ownership" (i.e. right of usufruct) lapsed in the case of permanent abandonment of the area and such land was returned to the control of the ward head who had it at his disposal.

* "Ownership" could not be transferred by the sale of land, nor could it be alienated in this way.

It can be assumed that during the early stages of contact between members of the adjacent Tswana category and the settlers of European extraction, the two land use systems discussed previously, and also the perceptions of the settlers regarding their land rights following their military victory over Mzilikazi, formed the background for interaction. As will be seen shortly, the servant class of Potchefstroom that accompanied the Boers, was always excluded from the dominant (Boer and British) category's system of land ownership. 
N.S. Jansen van Rensburg

\section{Actions to preclude the powerless from owning land in Potchefstroom}

An important early principle regarding ownership of land in Potchefstroom was embodied in the ZAR's Resolution 159 of 18 June 1855, which “... had precluded anybody who was not a burgher from owning land in the Transvaal, and had also precluded natives ${ }^{9}$ from burgher rights" (Davenport \& Hunt, 1974:40). Therefore, settlement in Potchefstroom was based on the allotment of land to citizens (burghers) and the ownership of land implied certain rights of citizenship. The dominant society did not accept individuals of mixed origin (the descendants of freed slaves and Afrikaans-speaking Africans) as equals or as citizens. The same applied to Tswana-speakers who, after the settlement of the Boers in the area, and the latter's conquest of Mzilikazi and his army, felt free to return to the surrounding area and also came to live in the Potchefstroom residential area as non-citizens (cf. Kruger, 1966:9).

Later, the position regarding land rights changed slightly when the Pretoria Convention of 1881 laid down that "Natives will be allowed to acquire land, but the grant or transfer of such land will in every case be made to, and registered in the name of, the Native Location Commission". Although this did not have a significant effect on the life of "blacks", their right to own land in the Transvaal was subsequently tested in the Transvaal Supreme court in 1905. Rev. E. Tsewu, who had bought land near Johannesburg, sought a court order to pass transfer of this land. Judgment was given in favour of the applicant (Davenport \& Hunt, 1974:40).

The most important action soon taken by the dominant category, however, implied the exclusion of the subordinates from inter alia their own land ownership system. They created an alternative system in which they imposed several prerequisites that would allow the subordinates certain restricted privileges regarding residence only. 10 This applied to both servants

9 This also applied in Natal where "The belief that the large majority of Africans in Natal were 'refugees' with no legitimate claim to land rights profoundly affected the final land settlement, and, indeed, became an important element in the colonists' 'social charter'. As late as 1880 the Natal Witness disputed the suggestion that Africans had any right to consider Natal as 'their country': 'They are here as immigrants on sufferance, and are not citizens ..." (Welsh, 1973:2-3).

10 These examples of actions at the local level must be seen in the context of the national phenomenon as embodied in laws. A complete exposition of these laws is found in Davenport and Hunt (1974).

Koers 60(4) 1995:593-618 
Limited access to land rights for the powerless in Potchefstroom

accompanying the immigrants and Tswana-speakers who had lived in the adjacent region for centuries.

\subsection{Limiting rights by authoritarian and one-sided actions}

Although the rights of subordinates in the Potchefstroom residential area had been severely restricted since the early days of the Zuid-Afrikaanse Republiek, (Jeppe \& Kotzé, 1887) Davenport and Hunt (1974:70-71) believe that the Stallard Commission (1922) created a clear "dogma", which, although its underlying assumptions were often seriously and continuously questioned, was taken for granted by various governments. This seems to be supported especially by the viewpoint that "... The towns had been built by and for White people, who alone could therefore claim rights there ..." (Davenport \& Hunt, 1974:70-71; cf. Davenport, 1971:13 et seq.).

An excellent example of the way in which some whites viewed the rights of "blacks" is reflected in the history of Potchefstroom. In a report, the Government Inspector of Urban Locations paid particular attention to the subdivision of stands by the authorities in Potchefstroom (Municipal file 3041, 17.03.1937). This report refers to the overpopulation of the "location" and the subsequent expediency (in the author's view) for certain existent stands to be subdivided. Still, the report finds it regrettable that the local authority built a road and did away with 25 existent stands, because: "Unfortunately there was no prior consultation with, nor was notice given to, the Natives concerned, who strongly resented the Council's action and at once took legal steps to protect their rights." The Mayor's reaction to this was that compensation would have to be paid for the improvements that were effected on the indicated stands and "... it was purely through an oversight that work was actually commenced without advising the residents affected (sic) ...".

The full extent of the assumptions behind these one-sided actions becomes clearer when, according to the Mayor: "... many of the natives appear to be under the impression that they have acquired special rights in (sic) the stands which they occupy and that their enjoyment of these rights cannot be interfered with in any way" (Municipal file 3041, 1937:7, 11, 12; cf. also Municipal file 2040, 23.03.1943 \& 550, 1936). In like manner, the Town Clerk also expressed his astonishment in 1937, when he heard that a "black" man acquired a court interdict on the basis that the scheme mentioned above, had interfered with his land rights, because "... the question of the rights of any Native in regard to the ground which it was proposed to subdivide never occurred to him ...", although the matter of compensation regarding houses did cross his mind (Meeting of the Native Administration Committee 08.05.1937, Municipal file 550, 1937). 
N.S. Jansen van Rensburg

It is also evident from a letter from the Town Clerk to the local Magistrate that the residents of the "location" increasingly protested against certain unacceptable measures "... on the ground that the stands which had belonged to them for very many years were being taken away from them illegally ..." and they threatened legal action (p. 2). Still, it is just as obvious that the Town Council, while viewing their own actions as "fair and reasonable", did not recognize these rights at all (p. 4,5$)$. The Town Clerk also had the impression that the residents were becoming unreasonable in their demands because "... there now seems to be an impression among the Natives that their views must be adopted in every case and that if this is not done they can have the necessary pressure brought to bear on my Council to force it to see the error of its ways simply by complaining to the Department of Native Affairs" (Municipal file $550,21.05 .1938)$.

A body that often advocated the interests of the residents of the "native location", the Joint Council of Europeans and Africans, also protested in 1937 and 1942 against the subdivision of existent stands. They saw this action as extremely short-sighted and believed that it was done against the wishes of the residents and the Native Advisory Board 11 (which included "blacks" and "coloureds"), and that these actions would only exacerbate overcrowding; the residential area should have been expanded. The reaction of the Town Clerk to this plea was only to the effect that the Town Council had obtained technical advice and that all the necessary authorities had approved the plans (Municipal file 2004, 1942; Municipal file 550, 1937).

The authoritarian actions of the Town Council and their disregard for the rights of the residents also had a bearing on more than the administration of residential stands. In 1944 the Council subdivided the sports grounds into residential plots. According to the residents, they did this without prior consultation with them, and for several years (probably five) the Council did not fulfil its promise for the creation of new sports grounds. The Potchefstroom African Football Association also alleged that the Municipality disposed of the sports grounds "without informing the people concerned" (Municipal file 3154, 13.06.1946).

11 The Native Advisory Board was first established in terms of the Native (Urban Areas) Act 21 of 1923. It was partly an elected and partly an appointed body, and it advised the white Town Council on the interests of the inhabitants of the location. The Superintendent, and later a member of the white local Council, functioned as its chairman (Riekert, 1963:89-108). 
Limited access to land rights for the powerless in Potchefstroom

The Council took similar authoritarian actions and decisions regarding the movement of individuals. The Superintendent 12 of the "location" refused an individual entry into the residential area because he had left a farm without the permission of his employer. The Superintendent suggested that if a letter of permission could be procured from the employer, "I will accept him" [sal ek hom aanneem], but added that the man had also insulted the Municipal police and was ill-mannered. Upon enquiry as to whether he was willing to reconsider the matter, he replied: "... if the man comes and apologizes, I will reconsider the matter" [transl. from Afrikaans] (Municipal file 2040, 1947).

\subsection{Labour as prerequisite for temporary residential rights}

The linking of residential rights to the supply of labour has always been an important principle in the administration of the affairs of South African "blacks". The South African Republic (ZAR) had used the tax system (Kruger, 1966:7-20) and other means to coerce "black" people into rendering services to people of European descent. The importance of labour as a prerequisite for residential rights in the creation of an alternative system of rights for the subordinate category can also be seen in the Town Regulations of the ZuidAfrikaanse Republiek, in which a principled stand is clearly expressed:

Each coloured [a comprehensive term] male over the age of 12 years, who resides in any town or city, shall have to be provided with a printed town pass, which shall include the name of his employer and duration of employment [transl. from Dutch] (Dorpsregulasies ZAP, 14.2.3, 10.02.1896, article 35).

The Stallard Commission reaffirmed this principle, namely the provision of labour, which regulated the presence of "blacks" in urban areas (viz. paragraph 42):

The native should only be allowed to enter urban areas, which are essentially the white man's creation when he is willing to enter and to minister to the needs of the white man, and should depart therefrom when he ceases to minister ... (Davenport \& Hunt, 1974:71).

The regulations determining mainly the rights of "blacks" (Bantu-speakers) in urban areas, gradually became more comprehensive and restrictive. This was

12 The local authority appointed this white official to supervise or control the "location" with respect to the allotment of stands in the location, collection of rent, keeping of a location register, approval of building plans and the issuing of residence permits (Riekert, 1963:22-25). 
N.S. Jansen van Rensburg

apparent in laws such as the Native (Urban Areas) Act, No. 21 of 1923.13 With regard to behaviour such as "habitually unemployed, idle, dissolute or disorderly life", the onus for proof of the opposite rested very soundly on the "native", who could, if found guilty, be removed from the urban area or sent to a work colony or similar institution (Davenport \& Hunt, 1974:71-72). Under this and subsequent statutory measures, eg. the Native (Urban Areas) Consolidation Act, 25 of 1945, individuals such as Noble Fertein [probably an Afrikaans-speaker of mixed descent], who, according to himself, was born in Potchefstroom, had his lodger's permit rescinded because he was unemployed (Municipal file 1484, 1945; cf. also Municipal file 1798, 1946 \& 1484, 1940). S.J. Parsons (Inspector of Urban Locations) reported similarly, that "natives" who were not usefully employed as labourers were "surplus and redundant" in the urban area of Potchefstroom (Municipal file 1798, 4-5.03.1946).

\subsection{Termination of the right of residence}

Certain circumstances such as age, ill health, ${ }^{14}$ possession of liquor and "undesirability" could, sometimes, lead to the termination of residential rights. Concerning the father-in-law of Frits Otto, who applied for the right of residence in Potchefstroom, the Superintendent replied as follows:

I wish to oppose this application on the grounds that the natives on whose behalf it is made are not desirable persons to reside in the location. There has been a tendency on the part of the native residents to import all their old relatives from the farms and other districts, mainly on the grounds of free medical services to this class of native by our Clinic. The present applicants claim that they have been turned off the farm by the owner on account of old age. I do not believe this story, and even if it is true, there seems to be more reason why they should be refused permission to reside here. ... I understand from Otto that his father-in-law is suffering from Tuberculosis, which in

13 The protest against these measures by bodies such as the S.A. Native National Congress, which was also active in Potchefstroom, was based on the same considerations as those found locally, namely, "having a share and claim to this country", the land being "the land of our ancestors" and "blacks" having contributed to "the progress and advancement of this country" (Davenport, 1971:21)

14 The so-called "sanitation syndrome" and state manipulation of planning regulations to protect working-class white residential conditions was an early mechanism by which South African cities were racially segregated (Pamell, 1993; cf. also Baines, 1990 and especially Swanson, 1977). 
Limited access to land rights for the powerless in Potchefstroom

itself is still a better reason for my refusal to the application (Municipal file 1799, 1933).

The use, possession or the sale of liquor was illegal for "blacks" and the contravention of these laws could result in the suspension of a residence permit (Municipal file 1484, 1939-40). So, for instance, Jan Tsumane, 76 years of age and a conditionally discharged leper, had lived in the "location" since 1919. During 1940 he was found guilty for being in possession of one gallon of spirits [Wittikies]. Because of this, his residence rights were suspended. He appealed to the Town Council against this suspension and was successful in his appeal (Municipal file 1484, 1940; cf. also Municipal file 1794, 1947). ${ }^{15}$ Not everyone was as lucky as Jan Tsumane. Another individual was guilty of transgression of these laws and the authorities decided to act against him in accordance with Act 21 of 1923, because they regarded him as "an idle, disorderly person", and they compelled him to leave the urban area of Potchefstroom (Municipal file 1484, 1940).

The authorities also viewed the following actions as disqualifications for residential permits: not being in permanent employment, being found guilty of receiving stolen goods, and being a polygamist. In one case, a member of the South African Police lost his residence permit because, "on several occasions [he] interfered with Municipal police" (Municipal file 2040, 1952). Sometimes there were no indications in the Municipal files about the nature of the transgression that resulted in the cancellation of residence permits of "undesirable" residents. One Henry Scorgie was given notice to leave the residential area "... because he is not a fit person, because his behaviour does not set a good example for the residents of the Location" [transl. from Afrikaans] (Municipal file 1793, 1949).

Whites experienced the presence and behaviour of people of colour as irritating, and saw their complaints regarding them as legitimate reasons for the latter's removal from what they perceived as the white part of town. These complaints of white residents included actions of "blacks" and "coloureds" allegedly playing football in the streets, drunkenness, disturbing the peace, cultivating land in town, competing in commerce, and sometimes what the complainants vaguely described as being "a nuisance". The merit of most of these complaints

15 This should be viewed against the background of the boom in the retail liquor trade, also among black mine workers in the last two decades of the nineteenth century when "... alcohol was a distinct aid in proletarianisating African peasants" (Van Onselen, 1982a:95; 44-102). 
N.S. Jansen van Rensburg

cannot be verified, whereas some were clearly without any foundation (Jansen van Rensburg, 1985:380-383).

\section{Dire implications of alternative systems of residence for the subordinates}

To attain a perspective on the importance and increasing influence of an alternative residential system for the subordinates, reference must be made to various aspects of life created and influenced by this alternative system. From evidence it becomes clear that the documentation used in this study, and specifically the regulations, cannot be seen as rhetorical statements only, but as a view on reality. The influences of an alternative residential system are reflected throughout the period of the existence of the "location" (1888-1969), and can be seen most clearly if one makes a comparison between the "real township", with its particular benefits and services, and the "alternate" one, called the native location, with its glaring deficiencies. The "native location" generally had unsatisfactory housing; ${ }^{16}$ and inferior roads and sanitation were reasons for dissatisfaction for several decades. ${ }^{17}$ During a certain period the residents of the "location" were prohibited from using the pavements in town; 18 there were definite restrictions on the use of water from the furrow, even if the town had a surplus (Municipal file 1799, 1941). Severe restrictions existed on trade; 19 the Town Council turned down an application by a businessman for the erection of a skating rink (Municipal file 1350 of 1909); an application for the erection of a church building was turned down, because there was no "white supervision" in that congregation; 20 overpopulation and overcrowding existed from the 1930's and became very serious from the 1950's onwards. ${ }^{21}$ All these living conditions can be associated with the creation of an alternative system of

16 Municipal files 1798 of $1946 ; 1793$ of 1946.

17 Municipal files 2905 of 1913-1926; 2901 \& 2040 of 1923-1945; 1549 of 1931; 1798 of 1946; 2377, $2905 \& 2372$ of 1954-1958; Anon., 1950.

18 Landdroste van Transvaal, 1852-1900; Municipal files 2031 of 1908; 2905 of 1920; 2031 of 1944.

19 Riekert (1963:41, 51, 72-74). Municipal files 532 of $1904 ; 3156$ of 1921 \& 1925; 1549 of 1949.

20 Municipal files 1794 of 1939; 1799 of 1950.

21 Municipal files 1550 of $1935 ; 3041$ \& 1798 of $1937 ; 1793$ of 1946, 1949 and 1950. 
Limited access to land rights for the powerless in Potchefstroom

residence for individuals classified as "blacks" and "coloureds" in which they had very limited choice (Jansen van Rensburg, 1985:301-386).

\section{Subordinates' experiences and actions within the system}

According to the documents from this period, starting from approximately 1901 , the subordinate category had already started reacting and adapting their claims to the one-sided rules laid down by the dominant category. With regard to obtaining rights to land, they based their claims on a variety of considerations such as length of residence, right of birth, perpetual right of occupation, incessant duration of residence, and obedience to the law.

\subsection{Bases for appeal: lengthy residence, right of birth, perpetual right of occupation, old age and obedience to the law}

Already in 1908 L. R. Muthle, who called himself "Secretary Potchefstroom Native Location", went to great lengths to claim certain rights for the residents ("Natives and Coloured British Subjects") of this area. He made an appeal to the Minister and Secretary of Native Affairs on the basis that "We are only poor Natives and Coloured people, but, we are loyal to our Government and King" (Muthle, 1908a). According to Muthle, the danger existed that the Potchefstroom Municipality, while taking control of the "location", did not recognize the rights of some residents. They based their petition on the argument that

The members of the Stadsraad [City Council during the reign of the ZAR] in the year 1888 at the time when the stands were first allotted, gave our fathers verbal Assurances to the effect that they were given a perpetual right of occupation of the stands allotted to them during their life time, as long as they paid their Annual rental of 10/- subject (sic).

According to this petition, the residents could alienate the land allotted to them and it could also be inherited. They regarded the actions that the Municipality had already taken, as "... a violation of Pledges and grave injustice" (Muthle, 1908b). The Secretary of Native Affairs reacted comprehensively to this petition. According to him, the Government believed that certain promises had really been made, but, that they had been made by the members of the old Stadsraad [City Council] and were ultra vires. Although certain concessions were made to the residents regarding rent, in other respects they were in the same position as the residents who had never lived in the "old location" [the same basic area, but created by the Zuid-Afrikaanse Republiek] (Secretary of Native Affairs, 29.04.1908). 
N.S. Jansen van Rensburg

On another occasion, the residents of the "location" requested the Town Council not to raise sanitation fees, and to exempt the many widows, the oldaged and orphans from the payment of rent. The official in charge ( $F$. van der Hoff) wrote the following comment on the request:

There are many Widows in this Location right enough. But they have children who can work for the White Community. But they are going to school instead ... and thereby, they are putting themselves and the white population on the same footing (Municipal file 2905, 1920; cf. also Municipal file 2345, 1912).

It also occurred that Johannes Afrika was found guilty on several occasions for the possession of "Barberton", a very potent home brew. The officials instructed him to leave the residential area. The Magistrate turned down his appeal against these measures. He accepted that he had a weak heart and was consequently not fit for employment, but this was not regarded as enough reason to retain his right of residence. Because of these occurrences, he complained as follows:

I have been borm in the location. I grew up here. Have been in the location even before Mr. Weeks, the Superintendent. Have married in the location. Now, I am in ill health and because of this Mr. Weeks refuses me permission to stay in the location [transl. from Afrikaans] (Municipal file 1484, 1944).

Elizabeth Tladi, who had lived in the residential area since 1901, had to leave town because of the transgression of liquor laws. Her son pleaded that she was old, had no other place to go to, and further implored:

I assume that you are aware of the fact that my late father has been living at Potchefstroom close on to 50 years and he died there, and was buried there. All his children ... [were] bom and brought up there, and we know no other home. To show that in truth we consider Potchefstroom as our only \& original home, even our Grand Father, my mother's father, lives right there. Now where shall we go to? Sir, as a Superintendent, you are like unto a father, and it falls upon you to have to make (sic) out punishment to your children at times, but I am sincerely appealing to you in this matter to just consider what this is going to mean to us (Municipal file 1794, 1949).

A general dispute - started in 1937 with the subdivision of stands in the "location" - was only concluded in 1941, and the Council only paid compensation to one person, namely, Souls. One individual applied for a court order and the matter was settled between him and the Town Council. Eighteen residents, however, drew up a memorandum and complained: 
Limited access to land rights for the powerless in Potchefstroom

We have been treated with much disrespect by both the Town Council and the Superintendent in that our stands which we have occupied for many years and for which we have regularly paid the Municipal dues have been cut up, reduced in size, our gardens ruined, our fences pulled down, and in spite of this we have not once been consulted nor considered, yet we have been obedient to all the rules and regulations of the location, also to the Superintendent. Hence we feel justified in asking still, for compensation to the extend (sic) of 25 pounds, for each stand ruined (Municipal file 550, $1941)$.

\subsection{Quests for remedies through available official channels}

Apart from verbal and written protests, those who felt unjustly treated used methods within the system that were regarded as functional and proper, such as initiating legal action and appealing to a variety of authorities. Sometimes they also started using their organizations, even if white authorities created these, to air their grievances. Legal action taken by the powerless not only implies their acceptance of these mechanisms for the solution of disputes, but also indicates that the subordinate individuals were already laying claim to the same basic rights as those enjoyed by the dominant category. So, for example, Andries Abrahams procured an interdict in 1937, preventing the subdivision of certain blocks of stands by Council. In this instance, Council decided that its lawyers should negotiate with the lawyers of those concerned regarding compensation for damages caused and infringement on the rights of residents - the consequences of work already undertaken by the local authority (Municipal file $550,1937)$.

Officials were often anxious that these legal actions might create the wrong impression among residents of the "location" regarding their rights. In 1946, S.J. Parsons (Inspector of Urban Locations) visited Potchefstroom and wrote a report. He referred to a court case (Solomon Mogotsi versus Rex), in which one of the Potchefstroom Location Regulations, which dealt with the renewal of stand permits, had been declared ultra vires. The official's concern is clearly reflected in his remark: "The Native concerned was said to be doing considerable mischief by announcing that local residents [are] no longer required to hold permits or to pay their dues" (Municipal file 1798, 1946:3).

Petitions to authorities also played an important role in expressing the discontent of those without real power. As early as 1908, the above-mentioned L.R. Muthle became involved in comprehensive correspondence and petitions directed at the Minister and Secretary of Native Affairs, and at Dr. W. Mortimer (M.L.A.). This correspondence concerned the perpetual right of the 
N.S. Jansen van Rensburg

residents on land in the "location". The documents in specific archives seem to indicate that these petitions had no perceptible effect (Muthle, 1908a \& 1908b).

Concerning the subdivision of stands since 1937, the residents protested because "... the stands which belonged to them for very many years were being taken away from them illegally ...". This claim was definitely not recognized by the local Council. The Council's opinion, as expressed to the Magistrate, was as follows:

While not disputing the right to approach the Department for legitimate reasons the attitude taken up by the Natives appears to be in a spirit which is not conducive to harmonious cooperation and which may give rise to considerable difficulty and unpleasantness in the future if it remains unchecked (Municipal file 550, Letter from Town Clerk to Magistrate, 21.05. 1938; cf. also Jan Tsumane's appeal to the Town Council, Municipal file 1484 \& 1794).

Council did not dispute the right of "blacks" to approach the Department for "legitimate reasons", but the nature of this "right" can be questioned, because the whole matter had been predetermined by the dominant category. Consequently, all actions by the underprivileged category would probably lead to "unpleasantness", because it questioned the status quo regarding ownership and the right of residence of people of colour in this urban area.

Organizations to which subordinates belonged, even those initiated by the white authorities, reacted in several ways to the unequal disposition regarding residential rights. At the 1942 Congress of the Local Native Advisory Boards, convened at Uitenhage, this body addressed a variety of requests to local authorities, of which a copy also reached Potchefstroom. This Congress opposed the existent system of housing, based on the principle of leasehold, and asked instead for the institution of freehold. They also asked for more flexibility regarding the enforcement of residence regulations if a "black" man obtained employment in another area. In such a case he should not forfeit his right of residence (Municipal file 1798, 1942).

At the local level, a meeting convened by the Native Advisory Board (also representing and including "coloureds") expressed their feeling of uncertainty and insecurity regarding residence in Potchefstroom's location. This did not earn a sympathetic response from the Superintendent who, during the debate, replied:

Supt. [Superintendent:] I say again, I did not come to oppress, but for cooperation. He also continued saying that the regulations were there to keep undesirable people from entering the location. E. Raboise [said] the 
regulations gave the superintendent sole power, what then would be the functions of the Council? [The] Chairman [said] the Council does not exist to find out who is good and who is bad, if that has been so, I do not want to be a member of the Council, and the same applies to the Town Council. Mohlabane [said] the regulations gave the Superintendent the [sole] right, why is the Council asked to approve of the Regulation? If a child of Potch. is removed, where must he go? Makhoere [said] for 10 years a man did the proper things, after this, something goes wrong, then he must leave the place, and where must he go? Supt. [said] a man behaves properly for 20 years then something goes wrong, then this man is sent back to his place of birth, and they must receive him there. [A motion was then carried that the approval of the regulations be postponed.] The Supt. then used harsh words in addressing the Council and asked whether the Council did not trust him, and whether they thought that if they passed the Regulation, he would say, 'Now I've got you' because he claimed to have come to do well [op te bou], and not to oppress [transl. from Afrikaans] (Municipal file 2040, 02.10.1946, p. 2).

\section{Conclusions}

At different times in the history of Potchefstroom, the powerful population categories of European extraction have dictated the allocation of vital resources such as land. Initially, most Tswana-speakers probably came to live in the urban area, possessing knowledge and a perception only of their own system of land use and allotment of land. This system implied relatively easy acceptance of individuals and families as new members of a "foreign" society, and the automatic and necessary allocation of land for subsistence, when one was accepted as a member. Acting against this background, they possibly expected perpetual and full use of land without individual ownership.

On the other hand, the dominant category viewed the land and the right to land as exclusively theirs. They assumed that their subordinates could procure temporary rights to the land only if their presence was beneficial to the interests of the dominant category. This applied to a broad category that also included people of "mixed" parentage, who were later classified as "coloureds", although apparently this applied to a lesser degree to this sub-category.

The dominant category excluded the subordinate category from their exclusive system of land ownership and its concomitant rules. The latter could not acquire land individually, and apparently this measure shared certain similarities with the communal system that generally existed among Bantuspeakers at the stage of contact with European settlers, because land was always "communal land". On the other hand, however, the most important dissimilarity to the communal system lies in the fact that the rights of "black" 
N.S. Jansen van Rensburg

people were severely restricted, and could be abrogated completely for very small transgressions - rules that were only applied to those who belonged to the subordinate category 22 . Within the land use system of Tswana-speakers, harsh actions such as these would amount to banishment (cf. Schapera, 1943:40; 107-108).

Non-allotted land (eg. the commonage where people of colour played football) and water sources were not freely accessible to "black" and "coloured" people, whereas land, because of its status as commonage and the status of water as a common resource, was accessible to all whites.

The entreaty of the subordinate category to acquire rights was vigorous, but was naturally limited to the rules and methods instituted by whites, because these applied within the land ownership system of the dominant category.

The history of residential segregation and accompanying differential land rights did not begin when the National Party introduced certain laws. It dates back inter alia to ZAR and British rule (Welsh, 1973; Mandy, 1984:34; Maylam, 1995) and its imposition by local authorities. The historical pattern in Potchefstroom gives some understanding of other actions of a restrictive nature regarding the land ownership of people of colour, namely the introduction of the devastating Land Acts of 1913 and 1936 (Davenport, 1987:392; Davenport, 1985:61 et seq.), the Native (Urban Areas) Act of 1923 and also the law on Group Areas (41 of 1950, 36 of 1966, 68 of 1986; cf. Festenstein \& PickardCambridge, 1987:1-6). These laws disregarded and severely infringed the rights of people of colour to land and their choice of residential area (cf. also

22 Differentiation regarding land rights imposed on the powerless was clearly based on colour. The severity of the situation regarding the treatment of "blacks" and "coloureds", can best be understood if Davenport's (1987) comparison between the treatment of blacks by whites on the one hand and, on the other hand, the actions of Britain after the Anglo-Boer War against Boers [and the 1914 rebellion], are considered. In white colonial expansion "The chief lost his political power, his subjects lost a source of livelihood, and it is important to note that two very different acts were being performed here ... Sovereignty and ownership are very different concepts ..." (Davenport, 1987:390). On the other hand, he states that "... the double seizure of the territory of the conquered ruler and the assets of his subjects was a practice frowned upon in South Africa in cases of conflict between whites. When the British took over the Transvaal in 1902, they did not deprive any burghers [or 1914 rebels] of their land" (Davenport, 1987:390-391) because they were not treated within a system of structural violence based on racial stratification. 
Jansen van Rensburg, 1985:373-409). Even up to the Verwoerdian era, the fundamental principles that were formulated regarding urban "blacks", entailed that they were seen as temporary residents of so-called white urban areas and that they thus lacked claims to property and citizenship rights (Olivier, 1984:356-357). Over a very long period, therefore, the authorities expounded a system regarding the right to the land, and made encompassing efforts to give it legality, while legitimacy was sorely lacking, especially among "blacks" and "coloureds".

Differentiation between whites and people of colour, and whites' evaluation of the worth of "black" and "coloured" people, can be connected to the creation of an alternative residential system. It is clear from many sources that these people were seen mainly as useful labourers and this again has some bearing on the idea of "guardianship" as inter alia embodied in the fact that, since the days of the old Transvaal Republic, the State President acted as "paramount chief" [opperste opperhoofd] of the "blacks" (Locale Wetten, 1884-1885:1352). There were specific regulations concerning the life of "blacks", viewed as necessary because of vast urbanization (since 1870) subsequent to the discovery of diamonds and gold. These regulations evolved into the creation of a pass or permit system for "blacks". Also, after the creation of the Union, the regulations for control of "blacks", Indians and "coloured" people in the colonies, were based on [paternalistic] ideals "... partly to cushion their unfamiliarity with the culture of the White man's cities, partly to control and canalize their labour, check their ill-health and prevent its contagion, deal with their misfits and contain crime" (Davenport, 1971:6; cf. Mandy, 1984:32 \& Parnell, 1993:479). Clearly, the importance of the statutory control of the movement of and influx of "blacks" to urban areas could mostly be connected to the importance of the demand and supply of "black" labour (cf. Olivier, 1984:364 et seq.; Davenport, 1971:10).

In the case of land policy in Potchefstroom and South Africa it is difficult to measure the range of "avoidable deprivation of life, measured in lost manyears" (Galtung \& Höivik, 1971:73). Likewise, an estimate of the effects of rapid change and the restructuring of South African society is almost impossible. South African society is not static and, therefore, it does not necessarily follow that the cessation of structural violence would, in an equalizing of opportunities, lead to gain for the disadvantaged and loss for the advantaged. Optimistically, one can argue that a less distorted society in South Africa and equal access to land would release resources that could bring the "average life expectancy" (Galtung \& Höivik, 1971:74) far above the previous level. 
N.S. Jansen van Rensburg

\section{References}

ANON. 1950. Gastro-enteritis: Incidence in Location, Forty Native Children Succumb. The Potchefstroom Herald, 6495:5, Febr. 10.

BOONZAIER, E. 1988. "Race" and the Race Paradigm. (In Sharp, J. \& Boonzaier, E., eds. South African Keywords; the Uses and Abuses of Political Concepts. Cape Town : Philip. p. 58-67.)

BAINES, G. 1990. The Origins of Urban Segregation: Local Government and the Residence of Africans in Port Elizabeth. c. 1835-1865. South African Historical Journal, 22:61-81.

CALDWELL, S. 1991. Segregation and the Plague: King William's Town and the Plague Outbreaks of 1900-1907. Contree, 29:5-10.

CHRISTOPHER, A.J. 1987. Race and Residence in Colonial Port Elizabeth. South African Geographical Journal, 69(1):30-20.

DAVENPORT, T.R.H. 1971. The Beginnings of Urban Segregation in South Africa: The Native (Urban Areas) Act of 1923 and Its Background. Grahamstown : Institute of Social and Economic Research, Rhodes University, Occasional Paper no. 15.

DAVENPORT, T.R.H. 1985. Some Reflections on the History of Land Tenure in South Africa, Seen in the Light of Attempts by the State to Impose Political and Economic Control. (In Bennett, T.W. et al. eds. Acta Juridica. Cape Town : Juta. p. 53-76.)

DAVENPORT, T.R.H. 1987. Can Sacred Cows be Culled? A Historical Review of Land Policy in South Africa, with Some Questions about the Future. Development Southern Africa, 4(3):388-400.

DAVENPORT, T.R.H. \& HUNT, K.S. 1974. The Right to the Land. Cape Town : Philip.

DORPSREGULASIES ZAP, 14.2.3, 1896.02.10, article 35 .

FESTENSTEIN, M. \& PICKARD-CAMBRIDGE, C. 1987. Land and Race; South-Africa's Group Areas and Land Acts. Johannesburg: SAIRR.

GALTUNG, J. 1969. Violence, Peace, and Peace Research. Journal of Peace Research, 6:167-191.

GALTUNG, J. \& HOIVIK, T. 1971. Structural and Direct Violence; a Note on Operationalization. Journal of Peace Research, 8:73-76.

HANCOCK, W.K. 1962. Smuts. Vol. 1. The Sanguine Years 1870-1919. Cambridge : University Press.

HORRELL, M. 1958. Race Classification in South Africa; Its Effect on Human Beings. Johannesburg: SAIRR.

JANSEN VAN RENSBURG, N.S. 1985. Die belewing van etniese grense in Promosa, Potchefstroom : PUCHO. (D.Phil.-proefskrif.) 
Limited access to land rights for the powerless in Potchefstroom

JEPPE, F. \& KOTZÉ, J.G. 1887. De Locale Wetten der Zuid-Afrikaanse Republiek 1849-1885. "33 Artikelen", Article 29. Pretoria : Z.A. Republiek.

KOTZÉ, D.A. 1984. Pleeg ons politieke geweld? Kaapstad : Human \& Rousseau.

KRUGER, B.J. 1966. Diskussies en wetgewing rondom die landelike arbeidsvraagstuk in die Suid-Afrikaanse Republiek, met besondere verwysing na die plakkerswette, 1885-1899. (Mededelings van die Universiteit van Suid-Afrika, C62.) Pretoria : Universiteit van SuidAfrika.

LANDDROSTE VAN TRANSVAAL. 1852-1900. Documents, 17 no. 91-127; 132-136. (Documents in Transvaal Archive Depot, Pretoria.)

LOCALE WETTEN der Z.A.R. 1884-1885. (Documents in Transvaal Archive Depot, Pretoria.)

MANDY, N. 1984. A City Divided: Johannesburg and Soweto. New York : St. Martin's.

MAYLAM, P. 1995. Explaining the Apartheid City: 20 Years of South African Urban Historiography. Journal of Southern African Studies, 21(1):19-38.

MUNICIPAL FILES. 1901-1952. Documents and Minutes of the Potchefstroom Municipality. (Documents in Transvaal Archive Depot, Pretoria and the Potchefstroom Municipal Archives.)

MUTHLE, L.R. 1908a. Letter to the Minister and Secretary of Native Affairs. 13 and 18 January. Potchefstroom. (Copy in Transvaal Archives Depot, Pretoria: sna 394 na 93/08.)

MUTHLE, L.R. 1908b. Petition to Dr. W. Mortimer (M.L.A.) 18 April. Potchefstroom. (Copy in Transvaal Archives Depot, Pretoria : sna 394 na 93/08.)

OLIVIER, N.J.J. 1980. Indigenous Land Law in South Africa. (In Sanders, A.J.G.M., ed. Southern Africa in Need of Law Reform. Pretoria : University of South Africa. p. 70-79.)

OLIVIER, N.J.J. 1984. The Legal Status of Urban Blacks in South Africa. Koers, 49(3):356-384.

POTCHEFSTROOM 1838-1938. 1939. Potchefstroom : Town Council.

PARNELL, S. 1993. Creating Racial Privilege: the Origins of South African Public Health and Town Planning Legislation. Journal of Southern African Studies, 19(3):471-488, Sept.

RASMUSSEN, R.K. 1978. Migrant Kingdom: Mzilikazi's Ndebele in South Africa. London : Collings.

RIEKERT, P.J. 1963. Bantoe-administrasie in Potchefstroom. Potchefstroom : PUCHO. (M.A. Verhandeling.) 
N.S. Jansen van Rensburg

RHOODIE, N.J. 1977. Sosiale stratifikasie en kleurlingskap. Johannesburg : McGraw-Hill.

ROOTHMAN, S. 1983. Strukturele geweld: 'n Konseptuele analise. Pretoria : UNISA. (M.A.-verhandeling.)

SANSOM, B. 1974. Traditional Economic Systems. (In Hammond-Tooke, W.D., ed. The Bantu-Speaking Peoples of Southem Africa. London : Routledge \& Kegan Paul. p. 135-176.)

SCHAPERA, I. 1943. Native Land Tenure in the Bechuanaland Protectorate. Lovedale : Lovedale Press.

SCHAPERA, I. 1962. The Tswana. London : International African Institute.

SAIRR

see

SOUTH AFRICAN INSTITUTE OF RACE RELATIONS.

SECRETARY of Native Affairs, 1908. Letter to Dr. W. Mortimer (M.L.A.) 29 April. Pretoria. (Copy in Transvaal Archives Depot, Pretoria : sna 394 na 93/08.)

SOUTH AFRICAN INSTITUTE OF RACE RELATIONS. 1949-1967. A Survey of Race Relations in South Africa. Johannesburg : SAIRR.

SUID-AFRIKA (Republiek). Kommissie van Ondersoek na aangeleenthede rakende die Kleurlingbevolkingsgroep. 1976. Verslag. Pretoria : Staatsdrukker. (RP 38/1976.)

SWANSON, M. 1977. The Sanitation Syndrome: Bubonic Plague and Urban Native Policy in the Cape Colony 1900-1909. Journal of African History, 18: 387-410.

THERON-KOMMISSIE

see SUID-AFRIKA (Republiek)

TUDEN, A. \& PLOTNICOV, L., eds. 1970. Social Stratification in Africa. London : Free Press.

VAN COLLER, H.M. 1983. Die burgerlike lewe in Potchefstroom ten tye van die Eerste Vryheidsoorlog. Potchefstroom : PUCHO. (M.A.verhandeling.)

VAN DEN BERGHE, P.L. 1970. Race, Class and Ethnicity in South Africa. (In Tuden, A. \& Plotnicov, L., eds. Social Stratification in Africa. London : Free Press. p. 345-71.)

VAN DER MERWE, C.G. 1989. Sakereg. Durban : Butterworths.

VAN DER VYVER, J.D. 1985. Die invloed van ras op 'n persoon se status. (In Van der Vyver, J.D. \& Joubert, D.J. reds. Persone- en Familiereg. Kaapstad : Juta. p. 276-321.)

VAN ONSELEN, C. 1982a. Studies in the Social and Economic History of the Witwatersrand 1886-1914. Vol. 1. New Babylon. Johannesburg : Ravan.

Koers 60(4) 1995:593-618 
VAN ONSELEN, C. 1982b. Studies in the Social and Economic History of the

Witwatersrand 1886-1914. Vol. 2. New Nineveh. Johannesburg: Ravan.

VORSTER, L.P. 1981. Grondbesit en grondgebruik by die Bakwena-Bamarea-Phogole. Potchefstroom : PUCHO. (D.Phil.-proefskrif.)

WELSH, D. 1973. The Roots of Segregation: Native Policy in Colonial Natal, 1845-1910. Cape Town : Oxford.

WEST, M. 1971. Divided Community; a Study of Social Groups and Racial Attitudes in a South African Town. Cape Town : Balkema. 